MUZIKOLOŠKI ZBORNIK - MUSICOLOGICAL ANNUAL XI, LJUBLJANA 1975

UDK 785.72(497.12) Kogoj

\title{
ANDANTE ZA VIOLINO IN KLAVIR MARIJA KOGOJA
}

\section{Borut Loparnik (Ljubljana)}

V Kogojevem pičlem komornem opusu je Andante za violino in klavir središčno delo, prvo po nastanku, najizrazitejše po umetniški teži. ${ }^{1} \mathrm{Ne}$ zato, ker skladatelj ni bil violinist, ampak zavoljo bistvene danosti njegovega muzikalnega mišljenja je 122 taktov te fantazije izrazito nevirtuozna, koncertantno neučinkovita glasba. Svojo moč in ustvarjalno samobitnost razkriva zgolj $\mathrm{v}$ intimnem čustveno-tonskem svetu, docela $\mathrm{v}$ skladu $\mathrm{z}$ avtorjevim prepričanjem, da je "glasba iz svoje snovi razvita umetnost, v notranjost človeka postavljena», ${ }^{2}$ da "sili v vedno večjo poglobitev, (da) hoče izločiti zunanji svet od notranjega, osredotočiti človeka v notranjščino njegove duše, prodreti vanjo in zajemati iz njenega dna», da sta njen predmet in vsebina "čustvo, zgolj estetično čustvo«. ${ }^{3}$ Improvizacijsko oblikovanje, torej samó psihološko utemeljeno členjenje in povezovanje novih domislekov pa motivičnih preobrazb $\mathrm{v}$ muzikalno logično (čeprav po klasičnih načelih preohlapno sklenjeno) celoto zato ni pomanjkljivost ali celo nedorečenost skladateljske zasnove, temveč osrednja poteza in načelo Kogojevega ustvarjanja. Šele kadar ju je moč vsaj nekoliko razbrati - največkrat ju komaj slutimo, ker poznamo le redke skice in vmesne različice končanih del - se začno odstirati dragocena ozadja in vzgibi umetniškega čiščenja in dozorevanja prvotnih melodično-ritmičnoharmonskih jeder. O njihovem nastajanju ne vemo sicer ničesar; le iz pričevanj sodobnikov je znano, da je bil Kogojev delovni postopek slejkoprej improvizacijski, torej klavirski (»rokodelski»), instrumentalno spodbujan in dopolnjevan, in ne miselni, v notranje zvenenje in odbiranje usmerjen stvariteljski razbor. ${ }^{4}$ Razlika je tu seveda skrajnje poenostav-

1 Sele iz poznih ustvarjalnih let, najbrže iz časa klavirskih Malenkosti in Poslednjih spevov, je ohranjen doslej nenatisnjeni Preludij, iz zadnjega, že močno z boleznijo zaznamovanega obdobja pa poznamo Sedem skladb za violino in klavir, ki so izšle 1960. leta $v$ I.jubljani kot prvi zvezek Antologije Kogojevih del (edicije Društva slovenskih skladateljev, št. 97; redaktorja Marijan Lipovšek in Rok Klopčič).

2 Kogoj M., O umetnosti, posebno glasbeni, DS XXXI (1918), št. 3-4, str. 92.

3 Ibid., str. 93.

4 Opiram se na spomine Josipa Vidmarja, Marjana Mušiča, Karola Pahorja in drugih, ki so o tem pisali ali mi pripovedovali, ter na časopisna poročila in 
ljena, vendar pojasnjuje osrednji vtis, ki spremlja njegovo glasbo: zasnova se $\mathrm{mu}$ je razraščala in oblikovala intuitivno, v nenehnem iskanju psihološko najresničnejših, najbolj zadetih odtenkov in sovisnosti, zato tudi mimo pozunanjenih, vsebinsko neobveznih gradbenih pravil tako imenovane formalne jasnosti, ki jo je (podzavestno) sprejemal samo takrat, ko je bila do kraja istovetna $\mathrm{z}$ globjo danostjo in muzikalnim razvojem skladbe. Andante nedvoumno potrjuje to bistveno vrednost Kogojevega umetni škega uresničevanja.

Značilno je, da so prve sodbe očitale delu premajhno kompozicijsko strnjenost in razvidnost: $s$ stališča šolske dognanosti in svojih načelnih prepričanj so imele gotovo prav. 5 Vendar jih najbrže ni toliko izzvala kritična ocena glasbe kolikor odgovor na poudarjeno novotarstvo, ki je vnaprej, kot bojno znamenje opredelilo avtorski nastop Bravničarja in Kogoja. Iz časniških napovedi koncerta ga je sicer težko izluščiti, ${ }^{6}$ kaže, da se je širilo predvsem ustno, očitno pa zveni iz zapisov glasbenih poročevalcev o tem večeru. Prispevek Emila Adamiča se pravzaprav ukvarja samo $s$ posplošenim, neanalitičnim dokazovanjem, bolje prepričevanjem bralcev: da so bile splašene in odklonilne domneve odveč, saj se je pokazalo, kako sprejemljiva, niti najmanj prekucuška so bila izvedena dela; da je škoda, ker je javno mnenje zakrivilo slab obisk. ${ }^{7}$ - Nasprotno je Stanko Vurnik, tedaj že odločni zagovornik novih umetnostnih iskanj, namenoma razumel koncert kot samoumevno, običajno prireditev. Priznal je sicer, da je "ravno tako pomena vreden kakor vesel dogodek v našem glasbenem življenju zadnjih let«, toda ocenil ga je iz zornega kota wobjektivne, linearne smeri, kakor (jo) kaže glasba naprednejših evropskih kulturnih središč.$^{8}$ Kogojevo slogovno opredelitev je dojel kot wabsolutno, intelektualistično smer po znani sodobni nemški analogiji SchrekerSchönberg" ter sklenil, da gre v »opisanem okviru za izrazno muziko, deloma s starimi, poznoimpresionističnimi, deloma $\mathrm{z}$ novimi, linearnimi sredstvi«.? Med tako začrtanimi spoznanji sta ga v Kogojevi polovici spo-

ocene o Kogojevih improvizacijah, s katerimi je občasno dopolnjeval recitiranje na akademijah in podobnih nastopih.

5 Andante sta krstila violinist Karel Jeraj in skladatelj pri klavirju, na koncertu del Matije Bravničarja in Marija Kogoja 25. maja $1925 \mathrm{v}$ ljubljanski Filharmonični dvorani.

6 Izhajale so teden dni pred nastopom $\mathrm{v}$ vseh ljubljanskih dnevnikih ( $\mathrm{z}$ nebistvenimi spremembami). Ena od njih je posebej opozarjala tudi na Andante v J VI, št. 118, 21. 5. 1925 ("Bravničar-Kogojev koncert») npr.: "Na sporedu je tudi istega skladatelja Andante za violino in klavir - prva slovenska skladba te vrste." Oznaka se je oprijela dela za nekaj desetletij.

7 - č (E. Adamič): "Koncert Bravničar-Kogoj», SN LVIII, št. 118, 27. 5. 1925. $\mathrm{V}$ bistvu je bila govorica obeh skladateljev Adamiču tuja: "Muzika, ki sem jo slišal, je še vino, ki vre... Površnemu poslušalcu bo težko ločiti muziko Kogojevo od Bravničarjeve, še težje ubraniti se čutu enoličnosti, ker navidezno ustvarjata z enakimi harmoničnimi, ritmičnimi, tudi tehničnimi sredstvi, kakor malodane vsa sodobna glasba.» Ob koncu svojega res samo časnikarskega poročila sicer obljublja, da se bo ih koncertu še povrnil«, vendar tega, kot večkrat ob podobnih zagotovilih, nikoli ni storil.

8 V. S. (S. Vurnik): "Koncert Bravničar-Kogoj», S LIII, št. 122, 3. 6. 1925.

9 Ibid. Ugotovitev je pravilna, če seveda sprejmemo Vurnikove tedanje vsebinske opredelitve pojmov. Pošteno je tudi priznal: "Kakor smo zadnja leta gle- 
reda najbolj privlačila dvojna Fuga v g-molu, prirejena za klavir štiriročno, ter duet iz "Črnih mask»: z njuno pomočjo je lahko poudaril skladateljev slogovni razvoj $\mathrm{v}$ tolikokrat oznanjano (in želeno) čustveno zadržanost, se pravi $\mathrm{v}$ novobaročno ali vsaj neromantično glasbeno snovanje.10 Razumljivo tedaj, da se mu Andante ni zdel posebno značilen, čeprav ga je uvrstil med močnejše trenutke večera;" najbrže potrjuje to tudi opomba, da je poslušalce is svojo toplo zvočnostjo Bravničar bolj vnel kakor abstraktni Kogoj«.12 - Še največ hvale je novo, umetniško gotovo prvo pomembno slovensko delo za violino in klavir doseglo $\mathrm{v}$ oceni Jutrovega kritika. ${ }^{3}$ Za razliko od Vurnika, v zavetju mnogo bolj priznanih nazorov in hkrati z očitno drugačnim namenom kot Adamič se pisec ustavlja ob ugotovitvi, da "skladbe Marija Kogoja nasploh niso tako moderne kakor bi pričakoval", češ da so njihovi melodični postopi "prav krotki in semtertja tudi malce neznatni«, najpomembnejši kompozicijski prvini, harmonija in kontrapunktična izdelava tém, pa "neredko zaide(ta) $\mathrm{v}$ teoretske vode, iz katerih se (avtor) ne reši kmalu». Sklep: "mestoma bogato invenciozno, na drugi plati pa spet prav borno«, torej neenakovredno. ${ }^{14}$

dali slike, ki so bile bolj za razum kakor za oko in analogno literaturo, se dajo Kogojeve skladbe $z$ večjim užitkom čitati kakor poslušati, s čemer se še nisem hotel dotakniti kvalitete teh del, ker smatram take pojave danes za tipične in za izraz časa, čeprav je taka glasba in taka umetnost le za majhen krog ljudi, večini pa je in bo ostala tuja.ı

10 "Višek dosedanjega razvoja so na tem koncertu pokazale Črne maske iz zadnje dobe ustvarjanja, ki so se stilno že določno nagnile $\mathrm{v}$ novo, dosti konkretnejšo smer.॥ (ibid.) Značilno je, da je ob tem popolnoma prezrl samospev Letski motiv ter odlomka iz scenske glasbe k Sofoklejevemu Kralju Edipu („Fragment iz Edipa«) in Ribičičevi otroški igrici V kraljestvu palčkov ("Hvala čarovnici»). Nič manj pomenljivo ni, da je obe klavirski skladbi, Più mosso ("Piano», št. 6) in Capriccio serioso (»Piano», št. 5 ali samostojno, danes neznano delo, kakor domneva Ivan Klemenčič v magistrski nalogi "Kompozicijski stavek v klavirskih skladbah Marija Kogoja», str. 202), označil za "primera modernih abstraktnih, subjektivnih teorizmov, v katerih Kogoj nanizuje (zdi se, da njegov talent ni avtokritičen...!) fantastične domisleke brez pravega osredotočenja in poglobljenjau.

11 "Andante za violino z lirskimi vrednotami se je tudi, na hvalo izvrstni in prečuteni izvedbi g. Jeraja [,] z uspehom dal slišati.u (ibid.)

12 Seveda moramo vsaj nekaj očitno bolj povprečnega vtisa, ki ga je skladba zapustila med ocenjevalci, pripisati Kogojevemu spremljevanju: mnogi sodobniki in redka poročila pričajo, da ni bil koncertno vešč pianist, še celo pa ne tonsko dovolj pretanjen muzik; domnevamo torej lahko, da njegova igra ni bila vzorna in ni zmogla vseh zahtev, ki jih je postavil izvajalcu kot skladatelj.

13 "Koncert Kogoj-Bravničar", J VI, št. 122, 27. 5. 1925. Članek je natisnjen brez podpisa, vendar je avtor bržkone Lucijan Marija škerjanc. Svojo prvo koncertno kritiko v J je objavil 1. 3. 1925; vse naslednje so izhajale nepodpisane, razen tista o koncertu Orkestralnega društva Glasbene matice pod njegovo taktirko, ki jo je prispeval -a. Za škerjančevo pero govorita tudi način presojanja in slog pisanja. Manj verjetno se zdi, da je Bravničarjev in Kogojev večer ocenil Anton Lajovic, čeprtav se je tisti čas večkrat oglašal v J. Svoje članke je namreč vselej podpisoval, vrhu tega pa so se mu takratna previranja evropske glasbe že kazala v ostrih nasprotjih med težnjami "svetovnega židovstva" in rastočega nacionalizma posameznih evropskih narodov (prim. njegova razmišljanja o drugem in tretjem festivalu SIMC 1925. leta $v$ Pragi in Benetkah: J, 24. in 29. 5 . ter 16. in 18. 9. 1925.). V kritiki, o kateri teče beseda, teh nazorov ni čutiti. 
Sodba se zdi kritiku veljavna za skoraj vsa predstavljena dela, vendar dodaja, da je bila pomanjkljivost «še najmanj zaznatna pri skladbi Andante za violino in klavir, dasi je tudi ta skladba napravila izrazit vtis fragmenta in nedovršenosti«. ${ }^{15}$

Pripombe, s katerimi so ocenjevalci pospremili krst Kogojevega komornega prvenca, razkrivajo tako poleg značilnosti naših tedanjih razgledov, nazorov in teženj tudi osrednji ugovor, ki se je domalega vselej pritikal kritičnim odmevom na njegova dela: da so oblikovno nedorečena, muzikalno neenovita, ne dovolj premišljena. Tudi če upoštevamo čas, ki se je pričel odmikati Kogojevim umetnostnim ciljem, različna izhodišča in namene razsojevalcev in najverjetneje povprečne izvedbe, ostaja del očitkov vendarle vreden pozornosti. Kot dokaz, kako vsaksebi so si bili skladateljevi kompozicijski postopki in okus sodobnikov. Kot opozorilo, da je izvirnost Kogojeve govorice po odporu in nedoumevanjih ob prvih nastopih vendarle začela pronicati v slovensko glasbeno zavest, vsaj takrat, ko je (nenamenoma sevé) znala ubrati dostopnejše poti ali se je vsaj obrobno dotaknila znanih tonskih razpoloženj, kakorkoli jih je potem prevrednotila in oblikovala. Bržčas je predvsem zaradi tega - in kajpak zavoljo naše skromne violinske literaturte - Andante kmalu obveljal za najboljše domače delo in postal ena redkih Kogojevih skladb, po katerih so segli izvajalci iz lastne pobude že med obema vojnama; ${ }^{16}$ bil je tudi avtorjeva

14 Ibid. To trditev utemeljuje ocenjevalec $\mathbf{s}$ krajšsim opisom Fuge $\mathrm{v}$ g-molu, ne da bi upošteval verjetno pomanjkljivo (vsekakor premalo plastično) izvedbo Antona Balatke in Heriberta Svetela, na katero opozarja Vurnik. Tudi se ne ozira na nekoliko vprašljivo možnost jasne tematske razvidnosti klavirskega zvoka $\mathrm{v}$ petglasni dvojni fugi.

15 štiri leta pozneje, v oceni prvega zvezka II. letnika Nove muzike (Nova muzika št. 1, J X, št. 74, 28. 3. 1929; članek je nepodpisan), je svoje mnenje precej omilil - dokaz več, da krstna izvedba res ni bila posebno dognana: "Marij Kogojev Andante za violino in klavir je ena redkih, če ne morda edina slovenska skladba te vrste. Slišal sem jo pred leti na nekem koncertu, moram pa reči, da v izdaji napravlja mnogo enotnejši in prav za prav pohlevnejši vtis. Široko razpeta melodična linija te skladbe je docela romantičnega značaja ter $\mathrm{v}$ nobenem oziru revolucionarna, kakor se je morda nekoč videla. Klavirska spremljava vsebuje mnogo topline ter me $\mathrm{v}$ svoji polnozvočnosti spominja na pozno nemško romantiko (Marx). Srednji del je medlejši, medtem ko je repriza prvega dela vznešena. polna lirike. V vsem jako spretno zložena kompozicija, ki ji le mestoma zmanjka elana, tako da ni skoz in skoz enako zanimiva.» - Izhodišča in okvir presoje se potemtakem niso spremenili, toda $\mathrm{v}$ kritikovih očeh je zrasla cena dela. V skladu $\mathrm{z}$ njegovimi nazori in citiranim smemo domnevati, da se mu je nemara prav Andante zdel Kogojeva najboljša stvaritev, saj mu je poskrbel za prvo doslej znano izvedbo na tujem: 9. Iebruarja 1939 sta ga $v$ ikoncertnem sporedu pod naslovom "Música slovena" zaigrali portugalskim poslušalcem violinistka Aida Calderia in pianistka Maria Luisa Schiappa Viana Nascimento. Njun nastop je bil sklepna točka škerjančevega predavanja o naših skladateljih $\mathrm{v}$ okviru katoliških oddaj portugalskega Radiodifundido dos Estúdios da "Rádio-Renascença» (spored je ohranjen $\mathrm{v}$ glasbeni zbirki NUK).

16 Prvi ga je zaigral na svojem javnem diplomskem koncertu 25. junija 1928 - in v poznejših letih še večkrat - Karlo Rupel; pri klavirju je bil Pavel šivic. Ruplov konservatorijski profesor Jan šlais, $\mathbf{s}$ katerim je diplomski nastop pripravil, je Andante igral 1940. in 1942. leta (prvič gotovo, drugič verjetno ob spremljavi Marijana Lipovška) v oddajah Radia Ljubljana, leta 1945 pa ga je (z Verro Rěpkovo pri klavirju) posnel za glasbeni arhiv Češkoslovaškega radia v Pragi. 
prva instrumentalna partitura, ki je po 1945. letu izšla $v$ samostojni izdaji. ${ }^{17}$ Seveda pomisleki o njegovi dognanosti $v$ tem času še niso ponehali. Najbolj jih pač priznavajo spremembe, s katerimi je Andante izvajal Igor Ozim: ${ }^{18}$ te spremembe se ne dotikajo samo tehnično razmeroma skromnega violinskega deleža, ampak posegajo globje. Ozim je na več mestih zlajšal klavirski stavek, se izognil klavirskim podvojitvam violinskega parta, tu in tam razredčil (le redko predrugačil) harmonsko zasnovo in nekajkrat izraziteje uravnal metrični potek. Celotna faktura je zato prosojnejša, a tudi neprimerno bolj običajna, koncertno uglajena, kompozicijsko in celo slogovno manj značilna - pomenljivo znamenje, da sta bila Kogojev glasbeni svet in izraz popolnoma sklenjena, enovita in vsebinsko skrajnje odtehtana..$^{19} \mathrm{~V}$ oceni koncerta, na katerem je bila predelava prvič izvedena, pa je Danilo Švara zapisal tudi sodbo, ki je delu slednjič priznala veljavo izjemnega stvariteljskega dejanja: "Ta Andante je ena najtehtnejših skladb naše literatrure in je kljub dolgi dobi, odkar je komponirana, še danes revolucionarna in marsikomu nedostopna. $\$^{20}$

Najbrže ne bo moč nikoli natanko dognati, kdaj je delo nastalo. Kot malone vselej pri Kogoju tudi o njem ni znano, da bi ga bila sprožila zunanja spodbuda - prošnja, naročilo ali priložnost za izvedbo -, zato smemo domnevati, da ga je rodila samohotna, čista ustvarjalna nuja. Ohranjena sta dva skladateljeva rokopisa: prvi je na začetku čistopis, a se končuje kot hlastni delovni zapis, drugi je pravi čistopis, očitno iz let po krstni izvedbi. ${ }^{21}$ Verjetno ga je avtor namenil natisu v Novi muziki,

$\mathrm{V}$ pismu (10. 2. 1975), s katerim mi je te podatke sporočil, tudi zatrjuje, da je Andante vselej izvajal po natisu v Novi muziki, ni pa se mogel spomniti, iz katerega prepisa sta delo naštudirala z Ruplom (samo domneval je, da ga je priskrbel njegov učenec). Zanimivo je tudi šlaisovo opozorilo, da ni upošteval Kogojevega napotka sul ponticello $\mathrm{v}$ zadnjih treh taktih skladbe: "... nisem bil prepričan o primernosti tega pripomočka. Občutil sem, da [je] Kogoj hotel izraziti notranje, oddaljeno doživetje, ilustrirat[i] razpoloženje duha, nahajajoč [ega] se v nadzemeljskih višinah. Uporabil sem svoje vrste sordino, ki [je] bolj točno, zvočno ilustrirala zamišljeno .... (prim. op. 18)

17 Marij Kogoj, Andante, violino \& piano; Ljubljana 1956, Državna založba Slovenije; redaktorja Karlo Rupel in Marijan Lipovšek. Rupel je v zadnjih treh taktih obdržal skladateìjevo interpretacijsko oznako sul ponticello, dodal pa ji je napotek sul G.

18 Revizija je bila končana 16. 10. 1953 (datum ob zadnjem taktu rkp., ki ga hrani Igor Ozim), prvič jo je igral na svojem recitalu v Ljubljani 25. novembra istega leta; pri klavirju je bila Hilda Horak. Kot Rupel in Lipovšek se je tudi on ravnal po natisu skladbe $\mathrm{v}$ NM; sklepnega interpretacijskega napotka ni sprejel in tudi ne označil v notah (po lastni izjavi ga je zamenjal $\mathbf{s}$ con sordino).

19 Zaradi skrbnega, umetniško poštenega in občutljivega odnosa do izvirnika bi zaslužila Ozimova revizija posebno obravnavo, zlasti tiste njene rešitve, ki so predlogi $\mathrm{v}$ prid, ker podčrtujejo in krepijo osrednje muzikalne poteze posameznih odlomkov.

20 Švara D., Koncert Igorja Ozima, Slovenski poročevalec XIV, št. 281, 28. 11. 1953. Kritik je pomotoma domneval, da gre samo za Ozimovo nobdelavo violinskega parta«.

21 Prvi je ohranjen $\mathrm{v}$ skladateljevi zapuščini in obsega pet običajnih velikih notnih listov, popisanih večidel $\mathrm{s}$ črnilom. Do t. 80 je (sicer ne vselej enako) skrbno izpisan, nato je pisava do t. 98 hitrejša in nekoliko nemirnejša. Od tu naprej se nadaljuje s črnilom samo violinski part; klavirski je skiciran s črnilom le v t. 102 in od t. 108 do konca skladbe, drugod je (precej nepopolno) označen 
kjer je bil Andante prvič objavljen.22 Za časovno opredelitev je pomemben seveda le prvi: pisava in vsaj nekateri bolj spremljevalni (pozneje večidel opuščeni) oktavni basovski postopi $\mathrm{v}$ klavirskem partu dokazujejo, da je nastajal okrog $19_{24}$. leta, torej $\mathrm{v}$ obdobju pesmi za mladino. O njihovi bližini govori tudi vznesena, presenetljivo sproščena in poudarjeno vokalno spevna melodična dikcija. Mogoče je potemtakem, da je Kogoj svojega komornega prvenca zasnoval že v Gorici, kjer je živel od poletja 1922 do pozne pomladi ali celo poletja 1923: prvih skic žal ne poznamo, toda prvi ohranjeni rokopis je očitno plod zgodnejših osnutkov. Ker vemo, kako počasi in $\mathbf{s}$ kolikšnim naporom je oblikoval sleherno delo, ni neverjetno, da je tudi Andante ustvarjal daljši čas. Poleg dokončnih, popravljenih, izpopolnjenih in nedokončanih odlomkov prvega rokopisa podpirajo tako misel še razločki med njim in danes znanim čistopisom: nemara so ju povezovale zavržene, zgubljene ali vsaj doslej neodkrite predelave. Vsekakor je bila skladba ( $v$ sedanjem zapisu?) končana do maja 1925. leta. Matija Bravničar se spominja, da je bil Kogoj z njo na moč zadovoljen: navduševala so ga predvsem mesta $\mathrm{z}$ melodično izrazito klavirsko spremljavo, odlomek, v katerem je združil tri po tonskem območju daleč vsaksebi postavljene glasove, sklepni takti ter tako imenovano dvojno stopnjevanje.23

s svinčnikom. $\mathrm{Z}$ istim svinčnikom in enako pisavo je Kogoj dodal tudi popravke, spremembe in nekaj dinamičnih napotkov $\mathrm{v}$ prejšnjih in naslednjih taktih. Da so nastale prve strani kot čistopis, dokazujejo tudi skoraj povsod natančno začrtane fraze ter pogosta artikulacijska in dinamična znamenja $v$ klavirskem deležu; zanimivo in značilno pa je, da je skladatelj naslov, torej tempo (in z njim svoje ime in priimek) dopisal nad začetek dela očitno šele po končanem skiciranju. - Malo verjetno je, da bi mu bil ta rkp. služil pri spremljavi na koncertu 25. maja 1925, že zaradi nepopolnih, s svinčnikom naznačenih taktov. Zdi se torej sprejemljivo, da je obstajal prepis, ki ga danes ne poznamo, zakaj čistopis, ohranjen $\mathrm{v}$ glasbeni zbirki NUK (MZ 2164/1955) je docela izdelan, predvsem pa zavoljo značilno drobnejše, bolj stisnjene in v duktusu že načete pisave - očitno poznejši. Kogoj mu je $\mathrm{v}$ violinskem partu dodal tudi več artikulacijskih oznak in lokov za fraziranje, česar prvič ni storil, ker ni dovolj poznal tehnike violinske igre (sprejel jih je torej lahko šele na nasvet Karla Jeraja ali po posvetu z njim, se pravi tik pred krstno izvedbo ali po njej). Ta čistopis obsega šest običajnih velikih notnih listov. S črnilom so izpisane str. 3-11; na tretji strani je v zgornjem desnem kotu pečat "Arhiv Glasbene matice Ljubljana», v zgornjem levem kotu pa je verjetno (urednik NM) Emil Adamič dopisal opombo notografu: "Die erste Zeile pausiert das Klavirı. $\mathrm{Na}$ ovojnem notnem listu je (najbrže tudi) Adamič zaznamoval še datum, ko mu je skladatelj svoje delo izročil $v$ natis: "N. M. 16/11 28.॥. Zaradi naglice, s katero je to označil, je mogoče mesec prebrati kot februar (II) ali november (11), vendar je slednji, sodeč po objavi, bržkone pravilnejši. Domnevati torej smemo, da je nastal čistopis jeseni 1928. leta.

22 NM II, št. 1 (februar 1929), str. 4-8 notnega dela: Andante - Marij Kogoj. Kakor pričajo odmevi v dnevnem tisku, je zvezek izšel sredi marca 1929.

23 Citiram iz razgovora $s$ skladateljem. Po njegovi izjavi je bil Kogoju vzor melodično izrazite in samostojne spremljave orkestrski delež $\mathrm{v}$ sklepnem prizoru Puccinijeve "Madame Butterfly" (Andante sostenuto, "O a me sceso dal trono«), za dvojno stopnjevanje pa je štel vzpone, $v$ katerih se glasbena misel po doseženem vrhu ne umiri, temveč se dvigne do novega viška ter tako še okrepi doživetje; sleđnje je občudoval $\mathrm{v}$ neki Chopinovi mazurki ter $\mathrm{v}$ ljubezenskem duetu opere "Pikova dama» P. I. Čajkovskega. Žal Bravničar ni znal označiti odgovarjajočih odlomkov $\mathrm{v}$ Andantu, bil pa je prepričan, da so njegovi spomini vezani prav $\mathbf{s}$ to skladbo. Sporočilo je vseeno pomembno: vsaj deloma nam po- 
Andante za violino in klavir poznamo torej $\mathrm{v}$ dveh različicah, med katerima je preteklo več let; druga različica je bila predloga za natis $v$ Novi muziki, po njem pa so se ravnale poznejša izdaja ter predelavi. ${ }^{34}$ Zaradi nepozornosti stavca in korektorja se je $\mathrm{v}$ prvo objavo pritihotapilo več napak, nekaj pa jih je zakrivil že Kogoj v čistopisu. Obojne se odtlej ponavljajo. Večidel gre sicer za pravopisne spodrsljaje in pomote, ki so zlahka razvidne, opozoriti pa velja na tiste spremembe, ki meglijo skladateljevo zamisel (vse so v klavirskem deležu):
t. 16
v NM je prvi akord $\mathrm{g}^{-c^{1}}$; pravilno je e-g-c ${ }^{1}$
t. 25
na zadnjo dobo je $\mathrm{v}$ NM osminka; pravilna je četrtinka
t. $52-53,1$
$\mathrm{v}$ obeh natisih je pedalni ton napačno notiran; pravilno je $\mathrm{D}_{1}-\mathrm{D}$

t. 72, d zadnja šestnajstinka je že v čistopisu pomotoma dis² (Kogoj jo je sicer popravil, vendar očitno šele po objavi v NM); pravilen je cis $^{2}$

t. $74, \mathrm{~d}$ med drugo osminko in četrtinko (ais ${ }^{1}$ ) manjka v NM vezaj

t. $75-76,1$ spremljevalna figura je $\mathrm{v}$ NM ritmično napačna; pravilno je

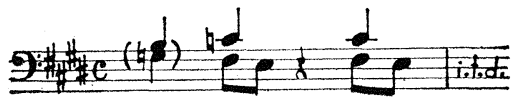

t. $78, d$ akord je v NM natisnjen kot fis ${ }^{1}-a^{1}$-dis ${ }^{2}$-gis ${ }^{2}$; pravilno je fis ${ }^{1}$-ais ${ }^{1}$-dis ${ }^{2}$-gis ${ }^{2}$

t. 80,1 že v čistopisu manjka pedalni ton F-f za ves takt, nakazujeta ga le vezaja $\mathrm{z}$ zadnje četrtinke $\left(\mathrm{C}_{1}{ }^{-} \mathrm{C}\right)$ prejšnjega takta.

t. 31, d prva doba je v NM ritmično triola; pravilna je kvintola

t. 87,1 že $\mathrm{v}$ čistopisu manjka pedalni ton $\mathrm{D}_{1}$-D za ves takt, zvezan $\mathrm{s}$ pedalnim tonom prejšnjega takta

t. 91,1 akord na drugo osminko prve dobe je v NM fis-ais-his-gis'; pravilno je fis-ais-his-e ${ }^{1}$

t. 103, d V NM se trilček izteče $v$ fis $^{3}$-gis $^{3}$; pravilno je fizis ${ }^{3}$-gis ${ }^{3}$

t.107, d V NM manjka drugi lok med tonoma cis ${ }^{1}$; pravilno je to mesto natisnjeno $\mathrm{v}$ prejšnjem taktu

t. 109, d že $\mathrm{v}$ čistopisu je sinkopirani četrtinski akord disi-ais'-dis²; pravilno je $\mathrm{d}^{1}$-ais $\mathbf{s}^{1} \cdot \mathrm{d}^{2}$

t.110, d V NM cis² ni zvezan z zadnjo osminko prejšnjega takta; pravilen je lok med njima.

jasnjuje za Kogojevo glasbo nenavadno močan in očiten vpliv poznoromantičnega opernega doživljanja in čustvovanja.

24 Poleg Ozimove revizije iz 1953. leta je leta 1973 nastala priredba Alojza Srebotnjaka za violino in orkester. 


\section{SUMMARY}

Marij Kogoj's Andante for violin and piano is not only his first and at the same time his best work of its kind, but it is also the first musically mature violin composition in Slovene musical literature. Written around 1924, it was for the first time performed by the violinist Karel Jeraj and the composer at the piano on May 25, 1925 at a concert in Ljubljana. On that occasion critics found the work weak in compositional compactness and uneven in musical ideas, not realizing that improvisational, psychologically founded modelling was to be the central feature of Kogoj's creative mind. The knowledge about this essential characteristic of his music spread only slowly, not infrequently through the help of the Andante. Two manuscripts of this work have survived; because of printing errors the published editions have obviously to all extent modified Kogoj's original ideas. 